Sani, G.

Arbusterin and its derivatives

Att. Acad. Lind.; through $J$. pharm. chim., 22 (Oct. 16, 1920), 312

Schmidt, $H$.

Aromatic antimony compounds

Ber.; through J. Soc. Chem. Ind., 39 (Nov. 30 , 1920), 763A

Schmidt, $H$.

Aromatic arsenic compounds

Ber.; through J. Soc. Chem. Ind., 39 (Nov. 1920), 763A

Sherk, D. C. I.

Physical constants of pure heptane

J. Am. Pharm. Assoc., 9 (Dec. 1920), 1153

Utz, F.

Solubility of hexamethylamine

Suddtsch A poth. Ztg.; through J. pharm. chim., 22 (Nov. 1, 1920), 353

\section{CLINICAL AND DIAGNOSTIC METHODS.}

Cruickshank

Value of the colloidal gold test

Brit. J. Exp. Path.; through Am. J. Pharm., 92 (Nov, 1920), 835
Eigenberger

Clinical significance of cylindroids

Zent. innere. Med.; through Am. J. Pharm., 92 (Nov. 1920), 834

Guillain, G., Laroche, G., and Léchelle

Reaction of colloidal benzoin with the cephalorachidian liquid

Compt. rend. soc. biol.; through J. pharm. chim., 22 (Nov. 1, 1920), 356

\section{MISCELLANEOUS.}

Coebergh, J. B. M.

Influence of light on medicaments

Pharm. Weekbl., 57 (Nov. 30, 1920), 1452

Éwe, G. E.

Laboratory notes

J. Am. Pharm. Assoc., 9 (Dec. 1920), 1178

Gershenfeid, L.

Bacteria in "soft drinks"

Am. J. Pharm., 92 (Nov. 1920), 803

Peters, W. A.

Perfume fixatives

Ungerer's Bulletin; through Drug. Circ., 64

(Dec. 1920), 454

\title{
COMMITTEE REPORTS
}

\section{INTERESTING HIGH SCHOOL STUDENTS IN THE PRACTICE OF PHARMACY.} BY CLYDE L. EDDY.

Chairman, Committee on Education and Legislation, New York Branch of the American Pharmaceutical Association.

Beginning in July 1923, the forty-five colleges of pharmacy now holding membership in the American Conference of Pharmaceutical Faculties will admit only high school graduates to their courses and, after 1925, a minimum course of three years of collegiate study will be required for graduation. Also, beginning in July 1923, the National Association of Boards of Pharmacy, including practically every pharmacy board in the United States, will put into effect a uniform requirement admitting only high school graduates to their examinations. Fifteen States now require both high school and college graduation and others will have similar requirements within a few years.

And this is but the beginning. Pharmacy is rapidly taking its place among the professions and it is conceivable that the pharmacist of but a few years hence will be on the same professional footing as his medical confrere. Conditions within the profession are becoming more and more attractive to men who have had long periods of collegiate and technical training. There are opportunities for the pharmacy student now which did not exist five or ten years ago. The present need is for more well-equipped young men and young women to take advantage of the opportunities that are offered. We need more "raw material" and, since that "raw material" ${ }_{\text {"must }}$ come from the high schools, we are confronted with the problem of interesting high school students in the practice of pharmacy.

Quick to see that the enforcement of prerequisite requirements might result in a shortage of apprentices in the profession and eager to prepare against such a contingency, the American Conference of Pharmaceutical Faculties is now seeking ways and means of best placing before 
high school students the advantages of pharmacy as a profession. A committee of the Conference has outlined a number of methods of accomplishing this and has called upon various pharmaceutical organizations for further suggestions. A letter from this committee, addressed to the New York Branch of the American Pharmaceutical Association, was recently handed to the Branch committee on education and legislation for consideration and action.

The committee, feeling that no one is better qualified to suggest such ways and means than the principals in charge of high schools, wrote letters to the principals of many of the local schools outlining something of the new status of pharmacy; the requirements for entering the profession; and the opportunities open for the high school student. They were asked what means they would suggest for reaching the students and the replies were prompt and significant. For instance, there is quoted below a letter from the vocational counselor of one of the largest high schools in the United States, a letter which indicates that the possibilities of pharmacy are little understood outside of the profession and that whatever information may be given to the high schools will not fall on barren ground. The letter follows:

"Your letter was most welcome. I believe that many of our students would be interested in pharmacy, if information could be given them in a simple, concise form. Would it be possible to prepare for distribution among our academic students, a folder which would state not only the advantages of pharmacy as a vocation, but also the kind and amount of preparation needed, the expense of such preparation, the schools where such preparation may be made, and the requirements of the Board of Regents?

"I should be thankful to you for any literature which would help to present this matter to the student."

Other letters of like tenor were received, almost every principal addressed showing a keen interest in the idea and suggesting one or more means of reaching the students. It is not necessary to publish the replies in full and perhaps the following summary will best indicate the methods of approach suggested by the several principals.

1. Have neat, four or eight page bulletins printed setting forth the advantages, requirements and opportunities in pharmacy and have these pamphlets distributed to high school students.

2. Distribute suitable pamphlets, bulletins or letters among high school teachers and ask them to call the subject matter to the attention of their students.

3. Many high schools publish weekly or monthly papers or journals and short, concise articles concerning pharmacy would find ready acceptance in the columns of such publications.

4. There are in most high schools regular assembly periods when talks could be delivered by competent persons, professors in nearby pharmacy colleges for instance, setting forth the requirements, etc., of students entering pharmacy.

These, then, would be the principal methods of approach and the bulletins, pamphlets, articles and talks should set forth clearly and concisely the present status of pharmacy; the requirement; for entrance; the cost of attending pharmacy colleges; and the opportunities open to pharmacy graduates in analytical and manufacturing laboratories, hospitals, the Army and Navy, the retail field, etc., etc.

High school principals and vocational counselors apparently are anxious to coöperatethe problem would seem to be not so much the method of approach as the much more mundane one of getting the propaganda work accomplished. State pharmaceutical associations should publish and distribute the necessary bulletins and pamphlets and the American Conference of Pharmaceutical Faculties should prepare a series of short articles for publication in the high school papers (this body might also furnish "copy" for the bulletins to be prepared by the State associations).

Finally, the member colleges of the Conference should get in touch with local high schools and be prepared to furnish speakers for assembly periods.

The matter of securing more young men and women in the profession is an important one and one which should have the careful consideration of all pharmaceutical organizations during the ensuing spring and summer. 